\title{
Effect of Lithium Doping on Microstructural and Optical Properties of ZnO Nanocrystalline Films Prepared by the Sol-Gel Method
}

\author{
Hung-Pin Hsu ${ }^{1}$, Der-Yuh Lin ${ }^{2, *}$, Cheng-Ying Lu ${ }^{2}$, Tsung-Shine Ko ${ }^{2}{ }^{\mathbb{B}}$ and Hone-Zern Chen ${ }^{3}$ \\ 1 Department of Electronic Engineering, Ming Chi University of Technology, No. 84 Gongzhuan Road, \\ New Taipei City 24301, Taiwan; hphsu@mail.mcut.edu.tw \\ 2 Department of Electronic Engineering, National Changhua University of Education, No. 2, Shi-Da Road, \\ Changhua 50074, Taiwan; M0453001@mail.ncue.edu.tw (C.-Y.L.); tsko@cc.ncue.edu.tw (T.-S.K.) \\ 3 Department of Electronic Engineering, Hsiuping University of Science and Technology, No.11 Gongye Road, \\ Taichung 41280, Taiwan; hzc@mail.hust.edu.tw \\ * Correspondence: dylin@cc.ncue.edu.tw
}

Received: 28 April 2018; Accepted: 16 May 2018; Published: 19 May 2018

\begin{abstract}
The} \mathrm{Zn}_{1-\mathrm{x}} \mathrm{Li}_{\mathrm{x}} \mathrm{O}(\mathrm{x}=0,0.01,0.03$, and 0.05$)$ nanocrystalline films were synthesized on silicon (Si) substrates by using the sol-gel method. The crystal structure and surface morphology of these films were investigated by X-ray diffraction (XRD) and field emission scanning electron microscopy (FE-SEM). We observed that the average grain size was gradually reduced with increasing doping Li content. Photoluminescence (PL) spectra show that increasing the Li content will deteriorate the crystalline quality and result in the decrease of ultraviolet emission from the excitonic recombination and the enhancement of visible emission from the recombination between the intrinsic defects. The current-voltage properties of $\mathrm{Zn}_{1-x} \mathrm{Li}_{\mathrm{x}} \mathrm{O}$ nanocrystalline films were also studied under dark and photo-illumination for photo-detection applications. The normalized photo-to-dark-current ratio $\left(\mathrm{I}_{\text {photo }}-\mathrm{I}_{\text {dark }}\right) / \mathrm{I}_{\text {dark }}$ has been enhanced from 315 to 4161 by increasing the Li content of the $\mathrm{Zn}_{1-\mathrm{x}} \mathrm{Li}_{\mathrm{x}} \mathrm{O}$ nanocrystalline films from zero to 0.05 .
\end{abstract}

Keywords: ZnO; Sol-Gel methed; nanocrystalline

\section{Introduction}

Wide band gap materials with transparent properties are important for photovoltaic and optoelectronic devices. Zinc oxide $(\mathrm{ZnO})$ is one of the attractive transparent compound semiconductor materials with wide band gap $(3.3 \mathrm{eV})$ and a large exciton binding energy $(60 \mathrm{meV})$ at room temperature [1,2]. Due to its specific properties, $\mathrm{ZnO}$-based optoelectronic devices are believed to be promising candidates for transparent electronics applications [3], such as in thin film transistors [4-6], solar cells [7,8], photodetectors, [9] and light emitting devices [10]. Furthermore, due to its high electromechanical coupling coefficients, $\mathrm{ZnO}$ can be used in surface acoustic wave devices and chemical biosensors [11]. ZnO crystals or films have been successfully prepared by various kinds of fabrication methods, such as Radio Frequency (RF) magnetic sputtering, chemical vapor deposition, pulsed laser deposition, and sol-gel methods. Those fabricating systems require high vacuum and complicated temperature control processes, while the sol-gel process offers more merits due to ease of control of the chemical composition and a much simpler method for large-area coating at a low cost [12]. To realize an electronic device consisting of $p$ - and/or $n$-type characteristics, the doping technique is an important issue. Until now, several studies on $\mathrm{ZnO}$ doped with group III elements [13-15], transition metals $[16,17]$, and other elements $[18,19]$ have been explored. The dopants may not only change the dominant crystal orientation, but also play an important role in the enhancement of the 
photo-to-dark-current ratio via the doping-induced defect states [20]. However, it is difficult to achieve good and reproducible $p$-type $\mathrm{ZnO}$ due to low solubility of the dopant and high self-compensation [21]. The $p$-type $\mathrm{ZnO}$ was reported by doping $\mathrm{Li}$ since the solubility of $\mathrm{Li}$ in $\mathrm{ZnO}$ can be up to 30\% [22]. The interest in using $\mathrm{Li}$ as the dopant in $\mathrm{ZnO}$ is based on its potential ability to act as a $p$-type dopant and ferroelectricity behavior as reported in II-VI semiconductors [23]. Due to its specific and interesting properties, further study of the microstructural and optical properties of lithium doping on of $\mathrm{ZnO}$ is not only thought-provoking, but also important.

In this paper, we report a study of the doping effect of Li atoms on the optical and structural properties of $\mathrm{Zn}_{1-x} \mathrm{Li}_{\mathrm{x}} \mathrm{O}(\mathrm{x}=0,0.01,0.03$, and 0.05 ) nanocrystalline films. The X-ray diffraction (XRD) and field emission scanning electron microscopy (FESEM) were used to characterize the crystal structure and surface morphology of $\mathrm{Zn}_{1-\mathrm{x}} \mathrm{Li}_{\mathrm{x}} \mathrm{O}$ nanocrystalline films. The emission behaviors were probed by the photoluminescence (PL) technique. In addition, we also carried out the current-voltage (I-V) measurements under dark and UV illumination to investigate their optical detection properties.

\section{Experimental}

The source solutions for the growth of $\mathrm{Zn}_{1-x} \mathrm{Li}_{\mathrm{x}} \mathrm{O}$ nanocrystalline films were prepared with the precursors of zinc acetate dihydrate $\left(\mathrm{CH}_{3} \mathrm{COO}\right)_{2} \quad \mathrm{Zn} \cdot 2 \mathrm{H}_{2} \mathrm{O}$ and lithium acetate dehydrate $\mathrm{C}_{2} \mathrm{H}_{3} \mathrm{LiO}_{2} \cdot 2 \mathrm{H}_{2} \mathrm{O}$ which were dissolved in stoichiometric proportions in deionized water. The concentration of metal ions was kept at $0.5 \mathrm{M}$ with lithium mole ratios of $0 \%, 1 \%, 2 \%, 3 \%$, and $5 \%$, respectively. We added ethanolamine into the solutions to obtain stable precursor solutions. After stirring at $150{ }^{\circ} \mathrm{C}$ for $1 \mathrm{~h}$ on a hotplate, we can obtain transparent solutions for crystal growth. A standard substrate cleaning process using ethanol (95\% purity), acetone ( $99.87 \%$ purity), isopropyl alcohol (99.9\% purity), hydrochloric acid (36\% purity) and deionized water was done before crystal growth. Then, the Si substrates were rinsed in deionized water and dried by flowing nitrogen gas. Each layer was grown on the Si substrate by a spin coater with three steps: the first step with spinning rate $=100 \mathrm{rpm}$ for $10 \mathrm{~s}$, then the second step with a spinning rate of $3000 \mathrm{rpm}$ for $30 \mathrm{~s}$, then setting the preheating temperature at $300{ }^{\circ} \mathrm{C}$ for 2 mins. Ten layers were stacked on $\mathrm{Si}$ substrates. Then, the samples were annealed at $600^{\circ} \mathrm{C}$ for $2 \mathrm{~min}$ by rapid thermal annealing (RTA) treatment with a heating rate of $600^{\circ} \mathrm{C} / \mathrm{min}$.

The XRD patterns were studied by using Rigaku D/max-2200 X-ray diffractometer with $\mathrm{Cu}-\mathrm{K} \alpha$ radiation. The surface morphology and cross-sectional views of $\mathrm{Zn}_{1-x} \mathrm{Li}_{x} \mathrm{O}$ nanocrystalline films were investigated by field emission scanning electron microscopy (FE-SEM, HITACHI S-4800) at $3.0 \mathrm{kV}$. For PL measurements, room temperature photoluminescence (RTPL) spectroscopy was used to measure optical emissions by an He-Cd laser with a wavelength of $325 \mathrm{~nm}$. In I-V characteristics, the samples were measured under dark and UV lamp illumination $(365 \mathrm{~nm})$ by an HP 4145 semiconductor parameter analyzer in an applied voltage from -5 to $+5 \mathrm{~V}$.

\section{Results and Discussion}

Figure 1 depicts the XRD patterns of $\mathrm{Zn}_{1-\mathrm{x}} \mathrm{Li}_{\mathrm{x}} \mathrm{O}$ nanocrystalline films with different $\mathrm{Li}$ contents from $x=0$ to 0.05 . It is clear from observations that only one main peak located at $2 \theta=34.56$ degree, which demonstrates that all the $\mathrm{Zn}_{1-\mathrm{x}} \mathrm{Li}_{\mathrm{x}} \mathrm{O}$ nanocrystalline films consisted of a unique phase. The $\mathrm{Zn}_{1-x} \mathrm{Li}_{x} \mathrm{O}$ nanocrystalline film is well crystallized in a wurtzite structure with a (002) preferred orientation in the direction parallel to the c-axis. The lattice constant of c-axis can be extracted to be $5.2069 \AA$ A. E. Nurfani et al. have reported that Ti dopants change the dominant crystal orientation from (002) to (103), and also slightly extend the c-axis of the ZnO lattice parameter [20]. The results obtained in this work show that the doping of $\mathrm{Li}$ atoms does not cause obvious structure changes or lattice extensions. This might be due to the fact that the radii of $\mathrm{Ti}^{2+}$ or $\mathrm{Ti}^{4+}$ ions are larger than those of $\mathrm{Li}^{+}$ions, because the atomic number of $\mathrm{Ti}$ is 22 while that of $\mathrm{Li}$ is only 3 . The inset presents the full width at half maximum (FWHM) values of the XRD peaks in a function of Li content. It is noticed that the intensity of the (002) peaks gradually decreases with increasing Li content, at the 
same time, the FWHM are constantly broadened. We also deduced the crystallite size of $Z_{n_{1-x}} \mathrm{Li}_{x} \mathrm{O}$ nanocrystalline films from the Debye-Scherrer's equation $[24,25] D=k \lambda / \beta \cos \theta$, where $k$ is the Scherer constant $(k=0.9), \lambda$ is the wavelength of the $X$-ray radiation $(0.154 \mathrm{~nm}), \beta$ is the FWHM in radians, and $\theta$ is the Bragg diffraction angle. The results are $39.8,36.9,35.6$, and $34.6 \mathrm{~nm}$ for $\mathrm{x}=0$, $0.01,0.03,0.05$, respectively. The crystallite size is decreasing, which is due to the crystalline quality deteriorating by increasing the doping concentration of the Li atoms.

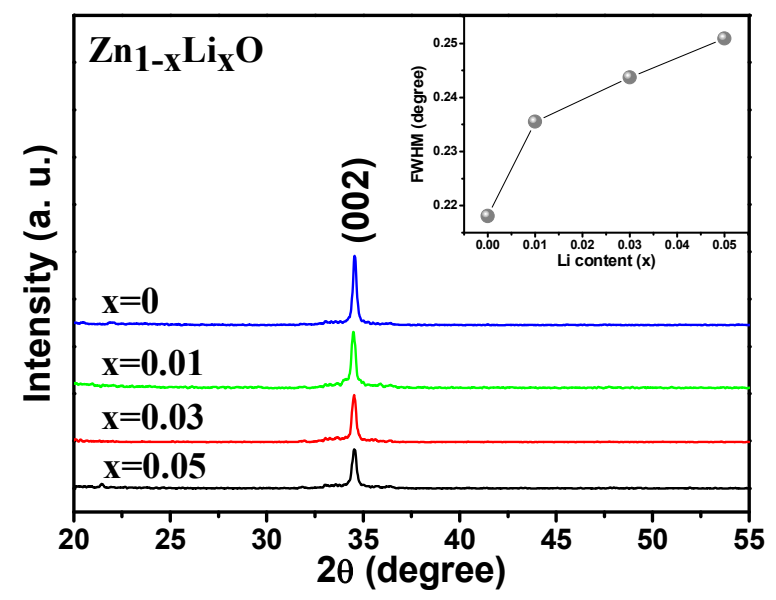

Figure 1. XRD patterns of $\mathrm{Zn}_{1-x} \mathrm{Li}_{\mathrm{x}} \mathrm{O}$ nanocrystalline films. The inset shows that FWHM broadens with various $\mathrm{Li}$ content.

The grain size of $\mathrm{Zn}_{1-\mathrm{x}} \mathrm{Li}_{\mathrm{x}} \mathrm{O}$ nanocrystalline films can also be observed by FE-SEM. Figure 2 shows both the surface morphology and cross-sectional views of $\mathrm{Zn}_{1-x} \mathrm{Li}_{x} \mathrm{O}$ nanocrystalline films. From the top view of $\mathrm{Zn}_{1-\mathrm{x}} \mathrm{Li}_{\mathrm{x}} \mathrm{O}$ nanocrystalline surface morphology, the average grain size is determined to be 88.02 to $71.16 \mathrm{~nm}$ for $\mathrm{x}=0$ to 0.05 , respectively, and it is observed that the average grain size is gradually reduced with increasing Li doping concentration. The tendency of grain change further confirms the observation in the XRD patterns. It is noted that the crystallite size is supposed to be the size of a coherently diffracting domain and is not exactly to be the same as the particle size [26] Furthermore, it has been found that the XRD peak can be widened by defects or internal stress, so the mean crystallite size calculated by the Debye-Scherrer's equation is smaller than the actual value [27]. In the side views, we can observe that the films are quite uniform with thicknesses of about $100 \mathrm{~nm}$ for all samples, and the pictures further confirm the c-axis orientation with columnar grains running perpendicular to the substrate.

Figure 3 presents the PL spectra of $\mathrm{Zn}_{1-x} \mathrm{Li}_{\mathrm{x}} \mathrm{O}$ nanocrystalline films for $\mathrm{x}=0$ to 0.05 taken at room temperature. The PL spectra consist of an ultraviolet (UV) emission peak and a weak green yellow visible (VIS) emission band. The sharp UV emission peaks resulted from the exciton recombination $[28,29]$. It is obvious that the PL intensity decreases with increasing Li doping concentration, which indicates that the doping Li atoms will deteriorate the crystalline quality. All the UV emission peaks seem located around $3.24 \mathrm{eV}$, and in careful observation we can find a slight blue shift with increasing Li doping concentration. The broader VIS emission below $2.4 \mathrm{eV}$ with a peak around $2.1 \mathrm{eV}$ reflects the characteristic luminescence associated with singly ionized defects, such as oxygen vacancy or doping-induced defects $[30,31]$ Comparing the intensity of the UV emission to the VIS emission, we observe the ratio of $\mathrm{I}_{\mathrm{UV}} / \mathrm{I}_{\mathrm{VIS}}$ is $8.68,4.21,2.52$, and 1.54 for various Li doping concentrations ( $x=0,0.01,0.03$, and 0.05 , respectively). We believe that the doping $\mathrm{Li}$ atoms are responsible for the decreasing ratio of $\mathrm{I}_{\mathrm{UV}} / \mathrm{I}_{\mathrm{VIS}}$.

Furthermore, we study the optical properties of these thin films by means of $\mathrm{I}-\mathrm{V}$ curves under dark and UV illumination. The photocurrent was measured by a 30-W Xe lamp with the incident wavelength of $365 \mathrm{~nm}$ as the irradiation source. In Figure 4, the I-V curves of $\mathrm{Zn}_{1-\mathrm{x}} \mathrm{Li}_{\mathrm{x}} \mathrm{O}$ nanocrystalline films were 
measured under dark and UV illumination in the voltage range from -5 to $+5 \mathrm{~V}$. For optical detection applications, the relative optical response can be defined by the normalized photo-to-dark-current ratio $\left(\mathrm{I}_{\text {photo }}-\mathrm{I}_{\text {dark }}\right) / \mathrm{I}_{\text {dark. }}$. The results at $+5 \mathrm{~V}$ are calculated and listed in Table 1 . This shows that the doping Li atoms are helpful to enhance the ratio of $\left(\mathrm{I}_{\text {photo }}-\mathrm{I}_{\text {dark }}\right) / \mathrm{I}_{\text {dark }}$, which has been raised more than ten times from 315 to 4161 .
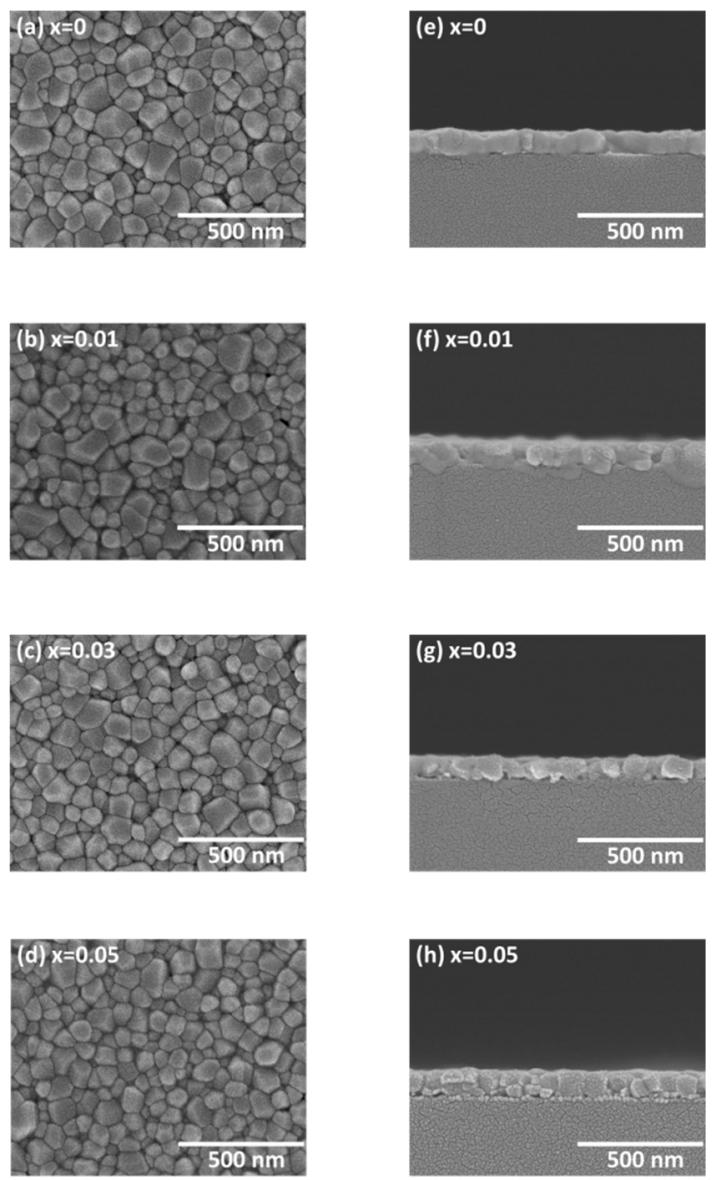

Figure 2. FE-SEM surface morphology (a-d) and cross sectional view images (e-h) of $\mathrm{Zn}_{1-\mathrm{x}} \mathrm{Li}_{\mathrm{x}} \mathrm{O}$ nanocrystalline films with $\mathrm{x}=0$ to 0.05 . The average grain size is determined to be 88.02 to $71.16 \mathrm{~nm}$ for $\mathrm{x}=0$ to 0.05 .

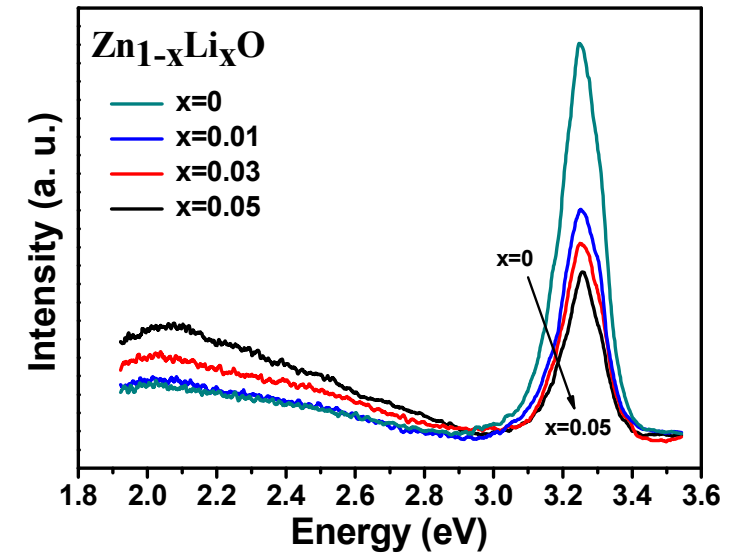

Figure 3. PL spectra of $\mathrm{Zn}_{1-\mathrm{x}} \mathrm{Li}_{\mathrm{x}} \mathrm{O}$ nanocrystalline films with $\mathrm{x}=0$ to 0.05 . 

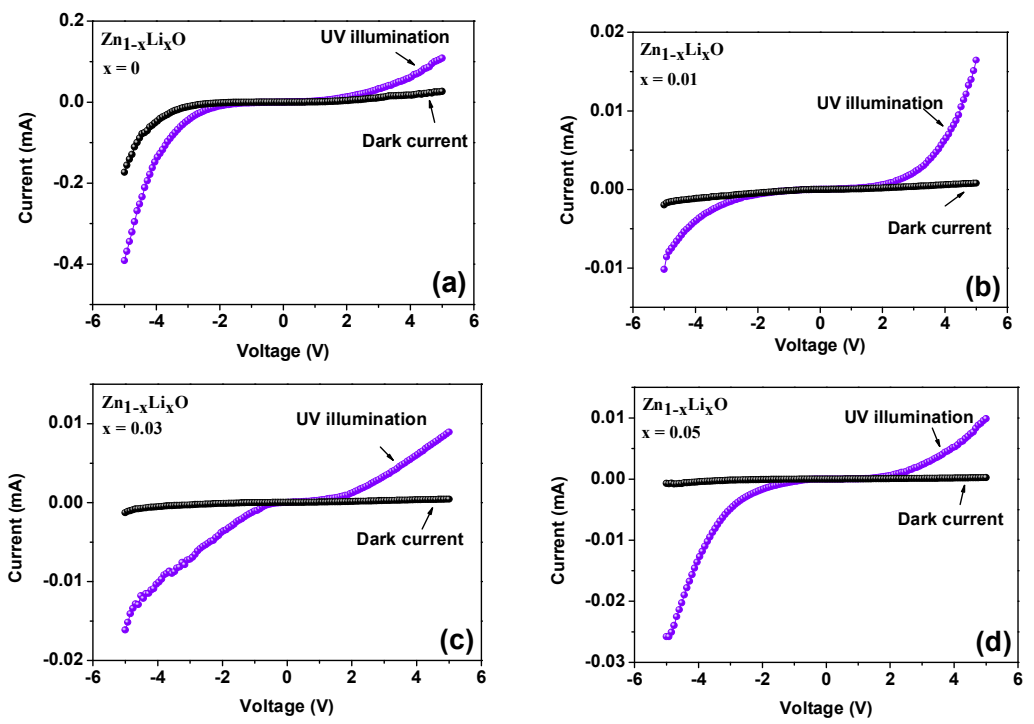

Figure 4. $\mathrm{I}-\mathrm{V}$ characteristics of $\mathrm{Zn}_{1-\mathrm{x}} \mathrm{Li}_{\mathrm{x}} \mathrm{O}$ nanocrystalline films [(a) $\mathrm{x}=0,(\mathbf{b}) \mathrm{x}=0.01,(\mathbf{c}) \mathrm{x}=0.03$, (d) $\mathrm{x}=0.05$ ] measured under dark and photo-illumination in the voltage from $-5 \mathrm{~V}$ to $+5 \mathrm{~V}$.

Table 1. Values of $\mathrm{I}_{\text {photo }}, \mathrm{I}_{\text {dark }}$, and $\left(\mathrm{I}_{\text {photo }}-\mathrm{I}_{\text {dark }}\right) / \mathrm{I}_{\text {dark }}$ at $+5 \mathrm{~V}$ of $\mathrm{Zn}_{1-\mathrm{x}} \mathrm{Li}_{\mathrm{x}} \mathrm{O}$ nanocrystalline films.

\begin{tabular}{cccc}
\hline $\mathbf{Z n}_{\mathbf{1}-\mathbf{x}} \mathbf{L i}_{\mathbf{x}} \mathbf{O}(\mathbf{x})$ & $\mathbf{I}_{\text {photo }}(\mathbf{m A})$ & $\mathbf{I}_{\text {dark }}(\boldsymbol{\mu A})$ & $\left(\mathbf{I}_{\text {photo }}-\mathbf{I}_{\text {dark }}\right) / \mathbf{I}_{\text {dark }}(\mathbf{\%})$ \\
\hline 0 & 0.1084 & 26.12 & 315 \\
0.01 & 0.0164 & 0.79 & 1975 \\
0.03 & 0.0089 & 0.41 & 2071 \\
0.05 & 0.0098 & 0.23 & 4161 \\
\hline
\end{tabular}

\section{Conclusions}

The $\mathrm{ZnO}$ doped with $\mathrm{Li}(0-5 \%)$ was successfully synthesized by the sol-gel method. XRD patterns showed a single crystalline phase of $\mathrm{Zn}_{1-\mathrm{x}} \mathrm{Li}_{\mathrm{x}} \mathrm{O}$. The composition-dependent crystallite size was deduced by Debye-Scherrer's equation, and further confirmed by the surface morphology from FE-SEM images. The PL spectra show a slight blue shift with an increase in Li content. The intensity of UV emission from exciton recombination decreases with increasing Li content, which is due to crystalline deterioration. The higher ratio of the normalized photo-to-dark-current ratio resulting from the doping of $\mathrm{Li}$ atoms demonstrates their potential in photodetector applications.

Author Contributions: H.P.H. and D.Y.L. conceived and designed the experiments. C.Y.L. and H.Z.C. prepared the materials. C.Y.L. and T.S.K. performed the experiments. H.P.H., D.Y.L., and T.S.K. analyzed data. H.P.H., D.Y.L., and H.Z.C. wrote the manuscript.

Acknowledgments: This work was financial supported by Ministry of Science and Technology of Taiwan under grant no. MOST 105-2112-M-018-006.

Conflicts of Interest: The authors declare no conflict of interest.

\section{References}

1. Özgür, Ü.; Alivov, Y.I.; Liu, C.; Teke, A.; Reshchikov, M.A.; Dogan, S.; Avrutin, V.; Cho, S.J.; Morkoç, H. A comprehensive review of $\mathrm{ZnO}$ materials and devices. J. Appl. Phys. 2008, 98, 041301. [CrossRef]

2. Özgür, Ü.; Hofstetter, D.; Morkoç, H. ZnO devices and applications: A review of current status and future prospects. Proc. IEEE 2010, 98, 1255-1268. [CrossRef]

3. Wager, J.F. Transparent electronics. Science 2003, 300, 1245-1246. [CrossRef] [PubMed]

4. Oh, B.; Kim, Y.; Lee, H.; Kim, B.; Park, H.; Han, J.; Heo, G.; Kim, T.; Kim, K.; Seo, D. High-performance ZnO thin-film transistor fabricated by atomic layer deposition. Semicond. Sci. Technol. 2011, 26, 085007. [CrossRef] 
5. Hirao, T.; Furuta, M.; Hiramatsu, T.; Matsuda, T.; Li, C.; Furuta, H.; Hokari, H.; Yoshida, M.; Ishii, H.; Kakegawa, M. Bottom-Gate Zinc Oxide Thin-Film Transistors (ZnO TFTs) for AM-LCDs. IEEE Trans. Electron Devices 2008, 55, 3136-3142. [CrossRef]

6. Fortunato, E.M.C.; Barquinha, P.M.C.; Pimentel, A.C.M.B.G.; Gonçalves, A.M.F.; Marques, A.J.S.; Martins, R.F.P.; Pereira, L.M.N. Wide-bandgap high-mobility $\mathrm{ZnO}$ thin-film transistors produced at room temperature. Appl. Phys. Lett. 2004, 85, 2541-2543. [CrossRef]

7. Pietruszka, R.; Witkowski, B.S.; Gieraltowska, S.; Caban, P.; Wachnicki, L.; Zielony, E.; Gwozdz, K.; Bieganski, P.; Placzek-Popko, E.; et al. New efficient solar cell structures based on zinc oxide nanorods. Sol. Energy Mater. Sol. Cells 2015, 143, 99-104. [CrossRef]

8. Vittal, R.; Ho, K.C. Zinc oxide based dye-sensitized solar cells: A review. Renew. Sustain. Energy Rev. 2017, 70, 920-935. [CrossRef]

9. Kind, H.; Yan, H.; Messer, B.; Law, M.; Yang, P. Nanowire ultraviolet photodetectors and optical switches. Adv. Mater. 2002, 14, 158-160. [CrossRef]

10. Liu, C.H.; Zapien, J.A.; Yao, Y.; Meng, X.M.; Lee, C.S.; Fan, S.S.; Lifshitz, Y.; Lee, S.T. High-Density, ordered ultraviolet light-emitting ZnO nanowire arrays. Adv. Mater. 2003, 15, 838-841. [CrossRef]

11. Du, X.Y.; Fu, Y.Q.; Tan, S.C.; Luo, J.K.; Flewitt, A.J.; Maeng, S.; Kim, S.H.; Choi, Y.J.; Lee, D.S.; Park, N.M.; et al. ZnO film for application in surface acoustic wave device. J. Phys. Conf. Ser. 2007, 76, 012035. [CrossRef]

12. Znaidi, L. Sol-gel-deposited ZnO thin films: A review. Mater. Sci. Eng. B 2010, 174, 18-30. [CrossRef]

13. Huang, Q.; Wang, Y.; Wang, S.; Zhang, D.; Zhao, Y.; Zhang, X. Transparent conductive ZnO:B films deposited by magnetron sputtering. Thin Solid Films 2012, 520, 5960-5964. [CrossRef]

14. Geng, Y.; Guo, L.; Xu, S.S.; Sun, Q.Q.; Ding, S.J.; Lu, H.L.; Zhang, D.W. Influence of Al doping on the properties of $\mathrm{ZnO}$ thin films grown by atomic layer deposition. J. Phys. Chem. C 2011, 115, 12317-12321. [CrossRef]

15. Zhao, J.L.; Sun, X.W.; Ryu, H.; Moon, Y.B. Thermally stable transparent conducting and highly infrared reflective Ga-doped $\mathrm{ZnO}$ thin films by metal organic chemical vapor deposition. Opt. Mater. 2011, 33, 768-772. [CrossRef]

16. Tsay, C.Y.; Cheng, H.C.; Tung, Y.T.; Tuan, W.H.; Lin, C.K. Effect of Sn-doped on microstructural and optical properties of $\mathrm{ZnO}$ thin films deposited by sol-gel method. Thin Solid Films 2008, 517, 1032-1036. [CrossRef]

17. Lin, C.C.; Young, S.L.; Kung, C.Y.; Jhang, M.C.; Lin, C.H.; Kao, M.C.; Chen, H.Z.; Ou, C.R.; Cheng, C.C.; Lin, H.H. Effect of Fe doping on the microstructure and electrical properties of transparent $\mathrm{ZnO}$ nanocrystalline films. Thin Solid Films 2013, 529, 479-482. [CrossRef]

18. Bhachu, D.S.; Sankar, G.; Parkin, I.P. Aerosol assisted chemical vapor deposition of transparent conductive zinc oxide films. Chem. Mater. 2012, 24, 4704-4710. [CrossRef]

19. Young, S.L.; Kao, M.C.; Chen, H.Z.; Shih, N.F.; Kung, C.Y.; Chen, C.H. Mg doping effect on the microstructural and optical properties of ZnO nanocrystalline films. J. Nanomater. 2015, 2015, 627650. [CrossRef]

20. Nurfani, E.; Zuhairah, N.; Kurniawan, R.; Muhammady, S.; Sutjahja, I.M.; Winata, T.; Darma, Y. Infulence of Ti doping on the performance of a ZnO-based photodetector. Mater. Res. Express 2017, 4, 024001. [CrossRef]

21. Chand, P.; Gaur, A.; Kumar, A.; Gaur, U.K. Structural, morphological and optical study of Li doped ZnO thin films on $\mathrm{Si}$ (100) substrate deposited by pulsed laser deposion. Ceram. Int. 2014, 40, 11915-11923. [CrossRef]

22. Lu, J.G.; Zhang, Y.Z.; Ye, Z.Z.; Zeng, Y.J.; He, H.P.; Zhu, L.P.; Huang, J.Y.; Wang, L.; Yuan, J.; Zhao, B.H.; et al. Control of p- and n-type conductivities in Li-doped ZnO thin films. Appl. Phys. Lett. 2006, 89, 112113. [CrossRef]

23. Fu, D.J.; Lee, J.C.; Choi, S.W.; Park, C.S.; Panin, G.N.; Kang, T.W. Ferroelectricity in Mn-implanted CdTe. Appl. Phys. Lett. 2003, 83, 2214-2216. [CrossRef]

24. Singh, A.K.; Viswanath, V.; Janu, V.C. Synthesis, effect of capping agents, structural, optical and photoluminescence properties of ZnO nanoparticles. J. Lumin. 2009, 129, 874-878. [CrossRef]

25. Rattana, T.; Suwanboon, S.; Amornpitoksuk, P.; Haidoux, A.; Limsuwan, P. Improvement of optical properties of nanocrystalline Fe-doped $\mathrm{ZnO}$ powders through precipitation method from citrate-modified zinc nitrate solution. J. Alloys Compd. 2009, 480, 603-607. [CrossRef]

26. Klug, H.P.; Alexander, L.E. X-ray diffraction procedures for polycrystalline and amorphous materials. J. Appl. Crystallogr. 1975, 8, 573-574.

27. Ashour, A.; Kaid, M.A.; El-Sayed, N.Z.; Ibrahim, A.A. Physical properties of ZnO thin films deposited by spray pyrolysis technique. Appl. Surf. Sci. 2006, 252, 7844-7848. [CrossRef] 
28. Kenanakis, G.; Androulidaki, M.; Vernardou, D.; Katsarakis, N.; Koudoumas, E. Photoluminescence study of ZnO structures grown by aqueous chemical growth. Thin Solid Films 2011, 520, 1353-1357. [CrossRef]

29. Banerjee, D.; Lao, J.Y.; Wang, D.Z.; Huang, J.Y.; Steeves, D.; Kimball, B.; Ren, Z.F. Synthesis and photoluminescence studies on ZnO nanowires. Nanotechnology 2004, 15, 404-409. [CrossRef]

30. McCluskey, M.D.; Jokela, S.J. Defects in ZnO. J. Appl. Phys. 2009, 106, 071101. [CrossRef]

31. Lin, B.; Fu, Z.; Jia, Y. Green luminescent center in undoped zinc oxide films deposited on silicon substrates. Appl. Phys. Lett. 2001, 79, 943-945. [CrossRef] 